\title{
Morphological variability of Rossiulus kess/eri (Diplopoda, Julida) from different biotopes within Steppe Zone of Ukraine
}

\author{
A. Pokhylenko', O.A. Lykholat ${ }^{2}$, O.O. Didur ${ }^{1}$, Yu.L. Kulbachko' ${ }^{1}$, T.Yu. Lykholat ${ }^{1}$ \\ ${ }^{1}$ Oles Honchar Dnipro National University, Gagarin Av. 72, Dnipro, 49010, Ukraine \\ ${ }^{2}$ University of Customs and Finance, Volodymyr Vernadsky St. 2/4, Dnipro, 49000, Ukraine \\ E-mail: Lykholat2010@ukr.net (or) vivtash@ukr.net \\ Received: 08.02.2019. Accepted: 06.03.2019
}

\begin{abstract}
Diplopoda play an important role in the processes of creating and maintaining soil fertility by implementing leaf litter destruction at its initial stages. Recently, in Ukraine the problem of soil fertility restoration has acquired a great urgency due to climate changes (aridity and temperature rising) and constantly increasing anthropogenic impact on natural biotopes, which often have Diplopoda as its element. The aim of this study was to evaluate the integrity of linear morphological characteristics of experimental animal Rossiulus kessleri (Lohmander, 1927) in different forest biotopes within semi-arid climate of the steppe zone. To determine the interrelation of morphological features, the method of correlation pleiades was used. It is established that 14 studied morphological characteristics of $R$. kessleri form the most powerful correlation pleiades with relative intensity values 0.64 and 0.93 , within natural subwatereshed-ravine landscape and terrace flood plain forest conditions respectively. However, weakened one with 0.07 relative intensity value is observed within standing forest. Generally, the integrity of morphological characteristics of millipedes is increasingly prominent in the natural forest biotopes and extremely low in forest stands. Morphological variability of diplopods identified sylvatization degree of julidae's habitat. Relative potency value of correlation pleiades can be used for diagnostics of forest stands naturalization within the steppe zone of Ukraine.
\end{abstract}

Keywords: Diplopoda; Rossiulus kessleri; morphological variability; correlation pleiade

\section{Introduction}

One of the main tasks of ecological safety is preservation of biodiversity, prevention of desertification and land degradation. It has acquired great importance in recent years in connection with the constantly increasing human influence on natural landscapes and natural communities in particular (Klymenko et al., 2017).

Degradation of lands can be defined as partial or ultimate destruction of the topsoil layer, characterized by a worsening of its physiological and biological state, decrease (loss) of soil fertility, which makes agricultural use of the territory limited or impossible. The international community has long recognized the fact that land degradation, accompanied by its dehumification and devegetation represents huge ecological and socially economical problem. These processes are typical for regions with significant anthropogenic pressure, for such highly industrialized region of Ukraine as Steppe Prydniprovie. The agrarian sector, industrial and mining enterprises are concentrated in this territory.

The main target in fighting with desertification is to prevent or decrease the scale of land degradation and restore partially degraded form desertification lands (Chibrik et al., 2016). Modern practice of disturbed landscapes restoration is wide and diverse; it includes creating standing forest and forest or agricultural reclamation methods. Ecological functions of soil can be good indicators of optimization efficiency for anthropogenically disturbed landscapes. One of the mechanisms of the restoration initiation and promotion is participation of living organisms in the transformation of organic matter in soil: destruction of dead plant residues with their further humification. Soil saprophages play a prominent role in organic matter transformation in the anthropogenically disturbed landscapes, they also called "ecosystem engineers" (Eisenhauer, 2010; Grimaldi et al., 2016; Didur et al., 2018a, 2018b). Their activity is mainly represented by regulation ecosystem services, such as maintenance of soil fertility and erosion prevention.

Among the soil invertebrates-saprophages, one of such representatives are millipedes (Myriapoda: Diplopoda). They play a key role in the primary decomposition of plant litter, the processes of soil formation and in soil biogeochemical cycle (Striganova, 1980; Gudym, 2016). They interact with fresh, recently fallen leaf-litter in the soil and mechanically grind it, improving the accessibility for treatment by microorganisms (Masse et al., 2018). Diplopoda is one of the largest classes of terrestrial arthropods. World fauna has more than 12000 species (Sierwald \& Bond, 2007). Only 10-15\% of the millipedes species are described for today, while the predicted number of species and subspecies will be about 80000 (Golovatch, 1997; 
Kime \& Enghoff, 2017; Masse et al., 2018).The typical and suitable habitats for millipedes are the deciduous temperate, subtropical and tropical forests where the population density of these animals can reach 1000 individuals per square metre (Golovatch \& Kime, 2009; Bogyó et al., 2015).

Due to semi-arid conditions of the steppe, the forest is located in geographical and ecological incompatibility. Therefore, natural forests in the steppe zone are located in river flood-plains, and confined to negative forms of relief (ravines, gullies, hollows), where the humidification conditions are improved. Worldwide practice shows that standing forest are created with the aim of forming shelter belts (Brygadyrenko, 2015), carrying out forest reclamation of man-made landscapes (Frouz et al., 2001; Lavelle et al., 2016), and forming a recreation zone (Tobias, 2013; Bakhmet \& Medvedeva, 2015). This is possible due to the following features: the first one is the ecological plasticity of tree species used in afforestation; the second is the strong environment-forming (pertinent) effect that standing forest has on ecological conditions of the forest itself.

Variability is a biological characteristic and contribute to adaptive phenotypic specimens' variation within the species and among its populations. Phenotypic variability is determined by diversity of conditions for living organisms' development and the hereditary variance of populations. Therefore, the morphological variability of Diplopoda, both at species and population level, inhabiting natural and standing forests, is due to hereditary variance (sexual structure) and to forest habitat conditions (geographic and ecological component).

Under the conditions of modern nature management, the degree of sylvatization in forest ecosystems is different. Therefore, integrity of millipedes' morphological parameters changes under the effect of sylvatization process. These changes appear itself at the level of morphological integration of Diplopoda characteristics. In soil-litter invertebrates, the most variable morphological characteristics of body size are linear parameters (Faly \& Brygadyrenko, 2007; Kulbachko \& Didur, 2017).

The aim of this study was to evaluate the integrity of morphological characteristics of experimental animal Rossiulus kessleri (Lohmander, 1927) in different forest biotopes within the steppe zone of Ukraine.

\section{Materials and methods}

\section{Study area}

The study sites are located at Dnieper Lowland within the steppe zone (left bank of north steppe province) and spans both natural forests and homogeneous ones. Administratively it is Novomoskovskyi, Pavlogradskyi, Juriivskyi districts within Dniepropetrovsk Region.

The R. kessleri specimens were collected in August-October, 2017 from three different forest biotopes (Fig. 1): natural ashmaple oakery, within subwatereshed-ravine landscape; natural maple-aspen oakery within terrace flood plain; and maple standing forest within subwatereshed-ravine landscape.

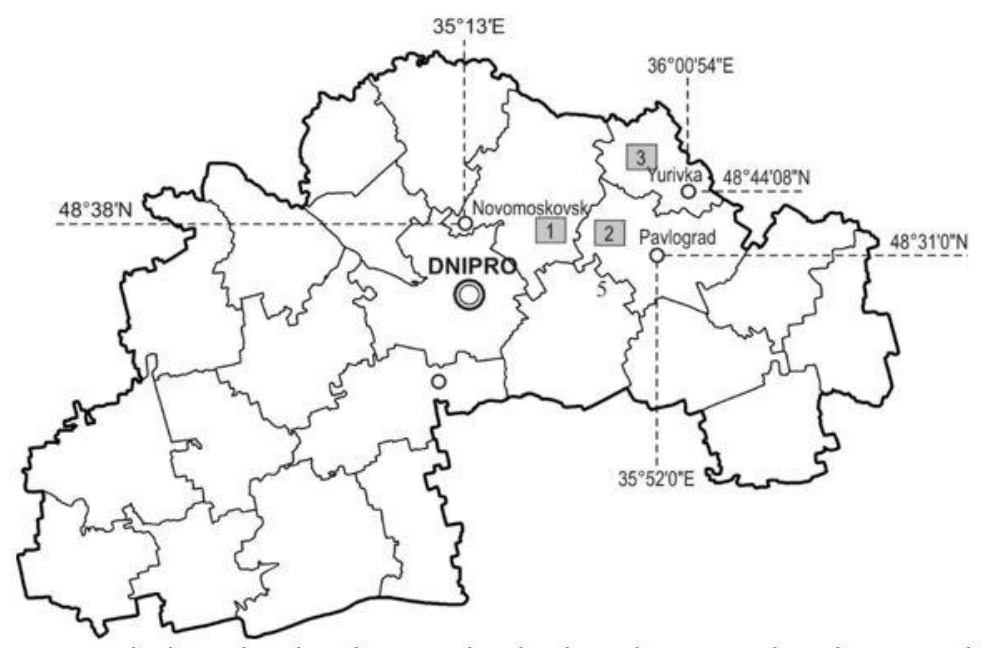

Figure 1. Research area map: 1 - natural ash-maple oakery (Novomoskovskyi district), 2 - natural maple-aspen oakery (Pavlogradskyi district), 3 - maple standing forest (Juriivskyi district).

Natural ash-maple oakery, within subwatereshed-ravine landscape (Novomoskowskyi district). The main tree species are English oak (Quercus robur L.), European ash (Fraxinus excelsior L.), English field maple (Acer campestre L.). Soil - Calcic chernozem (according to WRB classification) (IUSS Working Group WRB, 2015). Forest litter thickness was about $3 \mathrm{~cm}$, and it is composed of half-decomposed leaves.

Natural maple-aspen oakery, within terrace flood plain (Pavlogradskyi district). The basic forest species are European ash (Fraxinus excelsior L.), English field maple (Acer campestre L.). Soil - Phaeozem (according to WRB classification) (IUSS Working Group WRB, 2015). Leaf-litter was thick $1 \mathrm{~cm}$, integrated, compact.

Maple standing forest, within subwatereshed-ravine landscape (Juriivskyi district),composed of the trees English field maple (Acer campestre L.), Norway maple (Acer platanoides L.), Tatarian maple (Acer tataricum L.). Soil - Calcic chernozem (according to WRB classification) (IUSS Working Group WRB, 2015). The litter was fragmentary and thick $1.5 \mathrm{~cm}$. 


\section{Data analysis}

Rossiulus kessleri (Lohmander, 1927) (Diplopoda, Julida, Julidae), chosen as the experimental animal, is a widely distributed julid species in the mid-latitude forest, south oakery and standing forest. Millipedes (Myriapoda, Diplopoda) are detrivores, feeding mainly on decaying plant material, thus actively participate in fertility rising. The given species, $R$. kess/eri, is ecologically flexible and heliophile.

It is known that the integrity of the organism is ensured by the structural and functional integration of all its parts. In order to study the interdependencies of the morphological parameters of the given millipede, 14 characteristics were selected (Prishutova, 2001), and reflect: 1$)$ general body size: length $(L)$ and body width (l), number of segments $(S)$, telson length $(T)$, collar length (C), length of hindlimb (F); 2 ) the size of tactile organ: antennae length $(A)$ and width $(a) ; 3)$ the dimensions of the mouth apparatus parts: length $(G)$ and width $(g)$ of gnathochilarium, length $(E)$ and width $(e)$ of the lingular plates, length $(U)$ and width $(u)$ of the promentum. Gnathochilarium is a compound under lip (as the element of the second maxilla fusion), it's function is food bits supporting.

In order to compare the mean values of the morphological characteristics of males and females, the Honestly Significant Difference test, or the Tukey's HSD test (Mcdonald, 2014), was used with a significant difference. This criterion allows performing multiple paired comparison of averages correctly. The average difference with a confidence probability of $\mathrm{P} \geq 95 \%$ is considered statistically significant. The Tukey's HSD test was calculated within Statgraphics Centurion XV Version 15.1.02.

The investigation was complete during 2017-2018. Statistical analysis of the data was conducted using a set of statistical methods: descriptive statistics (Mean, Standard Error, Confidence Intervals); the gender differences were calculated by the Fisher test and considered statistically significant at $\mathrm{P}<0.05$; Pearson coefficient correlation was estimated.

The method of correlation pleiad by P. V. Terentyev (1977) was applied to analyze the correlation system. The given method is based on mathematical analysis of information array. As a result, the most stable correlated parameters are distinguished (so called "indicators"). The correlation pleiad includes the following indices: $G$ - pleiad intensity (number of characteristics, members of the pleiad), $G / k$ - relative potency ( $k$ is the total number of characteristics), and $D$ - pleiad stability (mean intrapleiad correlation coefficients absolute values).

This method can be used not only in soil-ecological researches, but also in other environmental studies. For example, it is used to determine the hydrochemical indicators effect on the homeostasis of some aquatic biota representatives (Klymenko et al., 2018).

The total experiment used 150 millipedes. Each individual was assigned a serial number including the ecosystem number and sex of the specimen (female, male). 14 linear characteristics were measured by micrometer eyepiece scale (MBS 9).

\section{Results}

According to the results, statistically significant differences among females, selected in three types of forest, were determined by body width (I) and body length (L), as well as by collum length $(C)$ (Table 1$)$. Individuals from maple standing forest are significantly different by larger body lengths compared to females from other forest types. Only for such morphological characteristic as promentum length $(U)$ statistical difference is not found.

Table 1. Statistical differences among females of $R$. kessleri from different forests types (Tukey test, $n=25, \mathrm{P}<0.05$ ).

\section{Characteristics. $\mathrm{mm}$}

Body length $(L)$

Body width (I)

Number of segments $(S)$

Length of hindlimb $(F)$

Telson length $(T)$

Length of the antenna $(A)$

Width of the antenna $(a)$

Gnathochilarium length $(G)$

Gnathochilarium width (g)

Length of the lingular plates $(E)$

Width of the lingular plates (e)

Promentum length $(U)$

Promentum width $(u)$

Collum length $(C)$

\section{Forests type}

natural ash-maple oakery
$31.16 \pm 5.129^{a}$
$3.22 \pm 0.181^{\mathrm{a}}$
$49.04 \pm 1.645^{\mathrm{a}}$
$1.23 \pm 0.305^{\mathrm{a}}$
$1.32 \pm 0.129^{\mathrm{a}}$
$2.052 \pm 0.286^{\mathrm{a}}$
$0.20 \pm 0.03^{\mathrm{a}}$
$1.20 \pm 0.086^{\mathrm{a}}$
$1.21 \pm 0.112^{\mathrm{a}}$
$0.32 \pm 0.067^{\mathrm{a}}$
$0.16 \pm 0.035^{\mathrm{a}}$
$0.33 \pm 0.046^{\mathrm{abc}}$
$0.23 \pm 0.036^{\mathrm{a}}$
$1.49 \pm 0.13^{\mathrm{a}}$

\section{natural maple-aspen oakery}

$32.00 \pm 2.598^{\text {ab }}$

$2.81 \pm 0.375^{b}$

$48.72 \pm 1.137^{\mathrm{ab}}$

$1.15 \pm 0.081^{\mathrm{ab}}$

$1.26 \pm 0.104^{\mathrm{ab}}$

$1.82 \pm 0.128^{\mathrm{ab}}$

$0.26 \pm 0.02^{\mathrm{b}}$

$1.22 \pm 0.069^{\mathrm{ab}}$

$1.25 \pm 0.049^{\mathrm{ab}}$

$0.49 \pm 0.041^{b}$

$0.23 \pm 0.020^{b}$

$0.34 \pm 0.044^{\mathrm{abc}}$

$0.22 \pm 0.035^{\mathrm{ab}}$

$1.39 \pm 0.094^{b}$ maple standing forest

$42.84 \pm 2.641^{\mathrm{c}}$

$3.74 \pm 0.300^{\mathrm{c}}$

$51.44 \pm 2.858^{\mathrm{c}}$

$1.32 \pm 0.128^{\mathrm{ac}}$

$1.60 \pm 0.204^{\mathrm{c}}$

$2.85 \pm 0.455^{c}$

$0.30 \pm 0.058^{b c}$

$1.33 \pm 0.09^{\mathrm{c}}$

$1.4 \pm 0.008^{\mathrm{c}}$

$0.47 \pm 0.041^{\mathrm{bc}}$

$0.23 \pm 0.024^{b c}$

$0.35 \pm 0.028^{\mathrm{abc}}$

$0.25 \pm 0.036^{\mathrm{ac}}$

$1.61 \pm 0.216^{\mathrm{c}}$

Note: The arithmetic mean and standard deviation are given for characterics.

Statistically significant difference among males from all forest types is determined by width $(a)$ and length $(A)$ of the antennae (Table 2). It should be noted that among the characteristics of the gnathochilarium elements (length and width of 
gnathochilarium itself, length and width of the lingular plates, length and width of the promentum) statistically significant difference by lingular plates length $(E)$ and width $(e)$, length $(G)$ and width $(g)$ of gnathochilarium is not established.

Table 2. Statistical differences among males of $R$. kessleri from different forests types (Tukey test, $n=25, \mathrm{P}<0.05$ ).

\section{Characteristics. $\mathbf{m m}$}

Body length (L)

Body width (I)

Number of segments $(S)$

Length of hindlimb $(F)$

Telson length $(T)$

Length of the antenna $(A)$

Width of the antenna $(a)$

Gnathochilarium length $(G)$

Gnathochilarium width (g)

Length of the lingular plates $(E)$

Width of the lingular plates $(e)$

Promentum length $(U)$

Promentum width $(u)$

Collum length $(C)$

\section{Forests type}

natural ash-maple oakery

$34.32 \pm 1.93^{\mathrm{a}}$
$2.78 \pm 0.28^{\mathrm{a}}$
$48.24 \pm 2.05^{\mathrm{a}}$
$1.28 \pm 0.12^{\mathrm{a}}$
$1.19 \pm 0.12^{\mathrm{a}}$
$2.33 \pm 0.28^{\mathrm{a}}$
$0.21 \pm 0.03^{\mathrm{a}}$
$1.10 \pm 0.08^{\mathrm{ac}}$
$1.12 \pm 0.11^{\mathrm{ac}}$
$0.39 \pm 0.05^{\mathrm{ac}}$
$0.20 \pm 0.04^{\mathrm{ac}}$
$0.31 \pm 0.05^{\mathrm{a}}$
$0.21 \pm 0.05^{\mathrm{ac}}$
$1.28 \pm 0.09^{\mathrm{ac}}$

natural maple-aspen oakery

$31.24 \pm 2.35^{\mathrm{b}}$

$2.38 \pm 0.18^{b}$

$47.92 \pm 1.22^{\mathrm{ab}}$

$1.14 \pm 0.09^{b c}$

$1.14 \pm 0.10^{\mathrm{ab}}$

$1.98 \pm 0.21^{\mathrm{b}}$

$0.23 \pm 0.02^{b}$

$1.04 \pm 0.10^{\mathrm{ab}}$

$1.09 \pm 0.08^{\mathrm{ab}}$

$0.40 \pm 0.04^{\mathrm{ab}}$

$0.21 \pm 0.03^{\mathrm{ab}}$

$0.30 \pm 0.05^{\mathrm{ab}}$

$0.20 \pm 0.04^{\mathrm{bc}}$

$1.24 \pm 0.09^{b c}$

\section{maple standing forest}

$32.64 \pm 2.33^{b c}$

$2.90 \pm 0.28^{\mathrm{ac}}$

$49.88 \pm 1.24^{c}$

$1.20 \pm 0.12^{c}$

$1.27 \pm 0.10^{c}$

$2.63 \pm 0.43^{c}$

$0.27 \pm 0.05^{c}$

$1.07 \pm 0.11^{\mathrm{abc}}$

$1.08 \pm 0.10^{\mathrm{abc}}$

$0.37 \pm 0.03^{\mathrm{abc}}$

$0.20 \pm 0.03^{\mathrm{abc}}$

$0.27 \pm 0.02^{c}$

$0.19 \pm 0.02^{\mathrm{abc}}$

$1.25 \pm 0.06^{\mathrm{abc}}$

Note: the arithmetic mean and standard deviation are given for characterics.

For Diplopoda's representatives, as well as for the majority of arthropods, sexual dimorphism is inherent. It appears as difference in size and color, or as the body structure between the sexes. According to the results of the measurement, sexual dimorphism for individuals from natural ash-maple oakery (Novomoskovskyi district) is determined by the following features $(P<0.001)$ : body width $I$, length of the antenna $A$, gnathochilarium length $G$, length of the lingular plates $E$, collum length $C$ (Table 3). Statistically significant difference between males and females is also observed by gnathochilarium size - females has it wider (8.8\%) and longer (6.3\%) than males.

The results for individuals from natural maple-aspen oakery (Pavlogradskyi district) showed statistically significant data $(\mathrm{P}<$ $0.001)$ in length of antenna $A$, males has it $7.6 \%$ longer, meanwhile sexual dimorphism in antenna width $a$ was absent $(P>$ 0.05). No statistically significant differences is observed in body length $L$, length of hindlimb $F$, and promentum width $u$.

For specimen from maple standing forest (Juriivskyi district) sexual dimorphism $(P<0.001)$ was noted for both main linear characteristics of the body (females $23.8 \%$ shorter and $22.5 \%$ thinner than males), whereas in the other two plots males and females significantly differ $(P<0.001)$ only by one main feature - width of the body $I$.

Structurogram of $R$. kessleri characteristics shows the connection level among the studied features (Fig. 2). In the natural ashmaple oakery (Novomoskovskyi district) a group of five parameters stands out: body length (L), number of body segments (S), telson length $(T)$, antenna size (length $A$ and width $\alpha$ ). In the given pleiad, antenna width $(a)$ can be considered as "indicator" due to the highest correlation coefficient (0.98).

It should be noted that promentum size (width $u$ and length $U$ ) is linearly independent from other parameters, which examined in the studied forest biotope. With that, the integrity of morphological characteristics of diplopods is higher in natural ash-maple oakery (Novomoskovskyi district) than in other plots. Thus, relative potency $(G / k)$ is equal to 0.93 , and pleiad stability $(D)$ is equal to 0.82 .

In natural maple-aspen oakery (Pavlogradskyi district) relative potency $(G / k)$ of pleiad is slightly low (0.64), and pleiad stability is alike 0.84 , what is almost equal to natural ash-maple oakery (Novomoskovskyi district). Indicator characteristic in this case is the telson length $(T)$ with a correlation coefficient of 0.99 .

Structurogram of $R$. kessleri characteristics in maple standing forest (Juriivskyi district) represents environmental disorder. Relative potency of this pleiad is equal to 0.07 , and pleiad stability is alike 0.78 . The integrity of morphological characteristics is not explicit.

Sexual dimorphism was detected by size of the head and, accordingly, in all linear measurements of its parts $(P<0,001)$ : gnathochilarium width $(g)$ and length $(G)$, width $(e)$ length $(E)$ of lingular plates, promentum width $(U)$ and length $(U)$, column length (C). It is interesting to note that statistically significant differences in the promentum width $(u)$ for $R$. kessleri from natural ash-maple oakery (Novomoskovskyi district) and natural maple-aspen oakery (Pavlogradskyi district) were absent.

Table 3. Statistical estimation of main morphometric characteristics of Rossiulus kessleri (Lohmander, 1927). 


\begin{tabular}{|c|c|c|c|c|c|c|c|c|c|c|c|c|}
\hline \multicolumn{5}{|c|}{ (Novomoskovskyi district) } & \multicolumn{4}{|c|}{ (Pavlogradskyi district) } & \multicolumn{4}{|c|}{ (Juriivskyi district) } \\
\hline \multirow[t]{2}{*}{$\begin{array}{l}\text { Characte } \\
\text { ristics }\end{array}$} & \multirow[t]{2}{*}{$\begin{array}{l}\mathbf{S} \\
\mathbf{e} \\
\mathbf{x}\end{array}$} & \multirow[t]{2}{*}{$\begin{array}{l}\text { Mean, } \\
\text { Standard } \\
\text { Error }(M \\
\left. \pm \mathrm{mt}_{0.05}\right)\end{array}$} & \multicolumn{2}{|c|}{$\begin{array}{l}\text { Statistical } \\
\text { confidence within } \\
\text { sexual } \\
\text { dimorphism } \\
\mathrm{F}_{0.05}=4.19\end{array}$} & \multirow[t]{2}{*}{$\begin{array}{l}\mathbf{S} \\
\mathbf{e} \\
\mathbf{x}\end{array}$} & \multirow[t]{2}{*}{$\begin{array}{l}\text { Mean, } \\
\text { Standard } \\
\text { Error }(\mathbf{M} \\
\left. \pm \mathrm{mt}_{0.05}\right)\end{array}$} & \multicolumn{2}{|c|}{$\begin{array}{l}\text { Statistical } \\
\text { confidence within } \\
\text { sexual } \\
\text { dimorphism, } \\
\mathrm{F}_{0.05}=4.19\end{array}$} & \multirow[t]{2}{*}{$\begin{array}{l}\mathbf{S} \\
\mathbf{e} \\
\mathbf{x}\end{array}$} & \multirow[t]{2}{*}{$\begin{array}{l}\text { Mean, } \\
\text { Standard } \\
\text { Error }(\mathbf{M} \\
\left. \pm \mathrm{mt}_{0.05}\right)\end{array}$} & \multicolumn{2}{|c|}{$\begin{array}{l}\text { Statistical } \\
\text { confidence withir } \\
\text { sexual } \\
\text { dimorphism, } \\
\mathrm{F}_{0.05}=4.19\end{array}$} \\
\hline & & & $\mathbf{F}$ & $\mathbf{p}$ & & & $\mathbf{F}$ & $\mathbf{p}$ & & & $\mathbf{F}$ & $\mathbf{p}$ \\
\hline $\begin{array}{l}\text { Body } \\
\text { length }(L) \text {, } \\
\mathrm{mm}\end{array}$ & $\sigma^{x}$ & $\begin{array}{l}31.2 \pm \\
2.01 \\
34.3 \pm \\
0.76\end{array}$ & 8.31 & 0.006 & $\sigma^{7}$ & $\begin{array}{l}32.0 \pm \\
1.02 \\
31.2 \pm \\
0.92\end{array}$ & 1.18 & 0.28 & $\sigma^{x}$ & $\begin{array}{l}42.8 \pm \\
0.63 \\
32.6 \pm \\
0.56\end{array}$ & 210.1 & $<0.001$ \\
\hline $\begin{array}{l}\text { Body } \\
\text { width }(/) \text {, } \\
\mathrm{mm}\end{array}$ & $0^{x}$ & $\begin{array}{l}3.22 \pm \\
0.07 \\
2.78 \pm \\
0.11\end{array}$ & 43.1 & $<0.001$ & $\sigma^{x}$ & $\begin{array}{l}2.81 \pm \\
0.15 \\
2.38 \pm \\
0.07\end{array}$ & 26 & $<0.001$ & $\sigma^{\prime \prime}$ & $\begin{array}{l}3.74 \pm \\
0.07 \\
2.90 \pm \\
0.07\end{array}$ & 104.8 & $<0.001$ \\
\hline $\begin{array}{l}\text { Number } \\
\text { of } \\
\text { segments } \\
(S)\end{array}$ & $\sigma^{x}$ & $\begin{array}{l}49.0 \pm \\
0.64 \\
48.2 \pm \\
0.80\end{array}$ & 2.32 & 0.13 & $\begin{array}{l}q \\
\sigma^{2}\end{array}$ & $\begin{array}{l}48.4 \pm \\
0.44 \\
47.9 \pm \\
0.48\end{array}$ & 5.74 & 0.02 & $\begin{array}{l}q \\
0^{\pi}\end{array}$ & $\begin{array}{l}51.4 \pm \\
0.68 \\
49.9 \pm \\
0.29\end{array}$ & 6.27 & 0.015 \\
\hline $\begin{array}{l}\text { Length of } \\
\text { hindlimb } \\
(F), \mathrm{mm}\end{array}$ & $\sigma^{\pi}$ & $\begin{array}{l}1.24 \pm \\
0.12 \\
1.28 \pm \\
0.05\end{array}$ & 0.46 & 0.5 & $\sigma^{\pi}$ & $\begin{array}{l}1.15 \pm \\
0.03 \\
1.14 \pm \\
0.04\end{array}$ & 0.11 & 0.74 & $0^{\pi}$ & $\begin{array}{l}1.32 \pm \\
0.03 \\
1.21 \pm \\
0.03\end{array}$ & 11.1 & 0.002 \\
\hline $\begin{array}{l}\text { Telson } \\
\text { length }(T) \text {, } \\
\mathrm{mm}\end{array}$ & $\begin{array}{l}q \\
\sigma^{\prime}\end{array}$ & $\begin{array}{l}1.25 \pm \\
0.05 \\
1.19 \pm \\
0.05\end{array}$ & 6.4 & 0.01 & $\begin{array}{l}q \\
0^{x}\end{array}$ & $\begin{array}{l}1.27 \pm \\
0.04 \\
1.15 \pm \\
0.04\end{array}$ & 16.7 & 0.0002 & $\begin{array}{l}q \\
0^{7}\end{array}$ & $\begin{array}{l}1.60 \pm \\
0.05 \\
1.28 \pm \\
0.02\end{array}$ & 50.1 & $<0.001$ \\
\hline $\begin{array}{l}\text { Length of } \\
\text { the } \\
\text { antenna } \\
(A), \mathrm{mm}\end{array}$ & q & $\begin{array}{l}2.05 \pm \\
0.11 \\
2.33 \pm \\
0.10\end{array}$ & 12.3 & 0.001 & $\sigma^{\pi}$ & $\begin{array}{l}1.83 \pm \\
0.05 \\
1.98 \pm \\
0.08\end{array}$ & 10.1 & 0.002 & $0^{\pi}$ & $\begin{array}{l}2.86 \pm \\
0.11 \\
2.63 \pm \\
0.10\end{array}$ & 3.23 & 0.08 \\
\hline $\begin{array}{l}\text { Width of } \\
\text { the }\end{array}$ & q & $\begin{array}{l}0.20 \pm \\
0.02\end{array}$ & 0.48 & 0.49 & q & $\begin{array}{l}0.26 \pm \\
0.010\end{array}$ & 14.9 & 0.0003 & & $\begin{array}{l}0.30 \pm \\
0.01\end{array}$ & 2.35 & 0.13 \\
\hline $\begin{array}{l}\text { antenna } \\
(a), \mathrm{mm}\end{array}$ & $0^{x}$ & $\begin{array}{l}0.21 \pm \\
0.01\end{array}$ & & & $0^{x}$ & $\begin{array}{l}0.24 \pm \\
0.009\end{array}$ & & & $0^{x}$ & $\begin{array}{l}0.28 \pm \\
0.01\end{array}$ & & \\
\hline $\begin{array}{l}\text { Gnatho- } \\
\text { chilarium } \\
\text { length }(G), \\
\mathrm{mm}\end{array}$ & $\sigma^{x}$ & $\begin{array}{l}1.21 \pm \\
0.03 \\
0.11 \pm \\
0.02\end{array}$ & 17.5 & 0.0001 & $\begin{array}{l}q \\
0^{\prime \prime}\end{array}$ & $\begin{array}{l}1.23 \pm \\
0.03 \\
1.04 \pm \\
0.04\end{array}$ & 58 & $<0.001$ & $\begin{array}{l}q \\
0^{x}\end{array}$ & $\begin{array}{l}1.34 \pm \\
0.02 \\
1.10 \pm \\
0.03\end{array}$ & 73 & $<0.001$ \\
\hline $\begin{array}{l}\text { Gnatho- } \\
\text { chilarium } \\
\text { width }(g) \text {, } \\
\mathrm{mm}\end{array}$ & $\begin{array}{l}q \\
\sigma^{\prime}\end{array}$ & $\begin{array}{l}1.21 \pm \\
0.04 \\
1.13 \pm \\
0.04\end{array}$ & 7.43 & 0.009 & 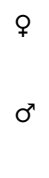 & $\begin{array}{l}1.25 \pm \\
0.02 \\
1.09 \pm \\
0.03\end{array}$ & 71.9 & $<0.001$ & $\begin{array}{l}q \\
0^{x}\end{array}$ & $\begin{array}{l}1.40 \pm \\
0.02 \\
1.08 \pm \\
0.02\end{array}$ & 141 & $<0.001$ \\
\hline $\begin{array}{l}\text { Length of } \\
\text { the } \\
\text { lingular } \\
\text { plates }(E) \text {, } \\
\text { mm }\end{array}$ & $\sigma^{\pi}$ & $\begin{array}{l}0.32 \pm \\
0.02 \\
0.39 \pm \\
0.01\end{array}$ & 25.7 & $<0.001$ & $0^{x}$ & $\begin{array}{l}0.49 \pm \\
0.02 \\
0.40 \pm \\
0.015\end{array}$ & 56.8 & $<0.001$ & $\begin{array}{l}q \\
0^{x}\end{array}$ & $\begin{array}{l}0.47 \pm \\
0.01 \\
0.38 \pm \\
0.007\end{array}$ & 83.94 & $<0.001$ \\
\hline $\begin{array}{l}\text { Width of } \\
\text { the } \\
\text { lingular } \\
\text { plates }(e) \text {, } \\
\text { mm }\end{array}$ & $\sigma^{x}$ & $\begin{array}{l}0.16 \pm \\
0.01 \\
0.21 \pm \\
0.02\end{array}$ & 16.7 & 0.0002 & $\begin{array}{l}\wp \\
0^{x}\end{array}$ & $\begin{array}{l}0.23 \pm \\
0.008 \\
0.21 \pm \\
0.01\end{array}$ & 8.25 & 0.006 & $\begin{array}{l}q \\
0^{\pi}\end{array}$ & $\begin{array}{l}0.24 \pm \\
0.006 \\
0.21 \pm \\
0.007\end{array}$ & 16.6 & 0.0002 \\
\hline $\begin{array}{l}\text { Promentu } \\
\text { m length } \\
(U), \mathrm{mm}\end{array}$ & $0^{x}$ & $\begin{array}{l}0.34 \pm \\
0.02 \\
0.31 \pm \\
0.02\end{array}$ & 4.97 & 0.04 & $0^{x}$ & $\begin{array}{l}0.35 \pm \\
0.02 \\
0.30 \pm \\
0.02\end{array}$ & 12.2 & 0.001 & $\begin{array}{l}q \\
0^{n}\end{array}$ & $\begin{array}{l}0.36 \pm \\
0.001 \\
0.27 \pm \\
0.005\end{array}$ & 152.5 & $<0.001$ \\
\hline $\begin{array}{l}\text { Promentu } \\
\mathrm{m} \text { width } \\
\text { (u), } \mathrm{mm}\end{array}$ & १ & $\begin{array}{l}0.23 \pm \\
0.01 \\
0.22 \pm \\
0.02\end{array}$ & 2.08 & 0.15 & $0^{x}$ & $\begin{array}{l}0.22 \pm \\
0.014 \\
0.20 \pm \\
0.017\end{array}$ & 1.77 & 0.19 & $\begin{array}{l}q \\
0^{x}\end{array}$ & $\begin{array}{l}0.26 \pm \\
0.009 \\
0.19 \pm \\
0.005\end{array}$ & 53.7 & $<0.001$ \\
\hline Collum & q & $1.49 \pm$ & 43.1 & $<0.001$ & q & $1.39 \pm$ & 28.2 & $<0.001$ & & $1.62 \pm$ & 63.4 & $<0.001$ \\
\hline
\end{tabular}




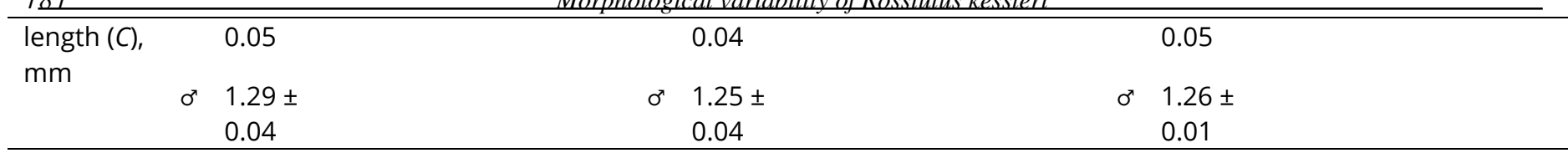

Note: $q$ - female $(n=25), o^{n}$ - male $(n=25)$ for each biotope

In summary, the diplopods are functionally active soil-litter component of zoocoenosis. Due to their activity in forest ecosystems, millipedes (in combination with other factors and processes) cause the naturalization of forest edaphotopes and, ultimately, the sylvatization of biotopes as a whole.

Thus, Diplopoda is an important biological factor in edaphotopes optimization, contributing to a humus layer formation and enhancing the ecological compatibility of forest vegetation with habitat conditions. We consider morphological variability of $R$. kessleri reflect the sylvatization degree of studied forest ecosystems. This hypothesis is confirmed by calculated results of relative potency: for $R$. kessleri individuals from natural forest ecosystems (Novomoskovskyi district, Pavlogradskyi district) this index range within 0.6-0.9, while for specimens from standing forest (Juriivskyi district)it is close to zero and equal to 0.07 .

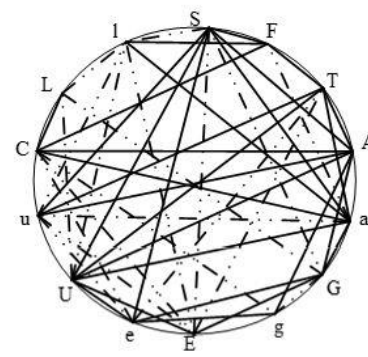

Natural ash-maple oakery, within subwatereshed-ravine landscape (Novomoskovskyi district)

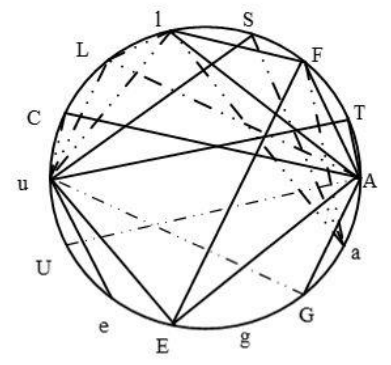

Natural maple-aspen oakery, within terrace flood plain (Pavlogradskyi district)

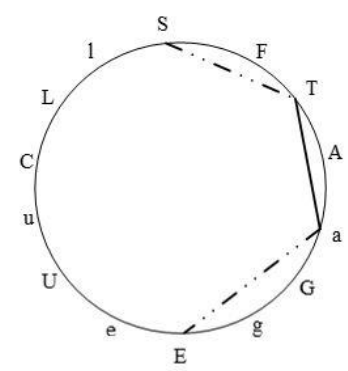

Maple standing forest, within subwatereshed-ravine landscape (Juriivskyi district)

moderate interaction strength $(r=0.4-0.7)$, strong interaction $(r=0.7-1.0)$

Figure 2. Correlation structure of $R$. kessleri characteristics.

\section{Conclusions}

One indicator of the integrity of diplopods' morphological characteristics is pleiad intensity. It is established that 14 morphological characteristics of $R$. kessleri form major pleiades within natural forest conditions (subwatereshed-ravine landscape and terrace flood plain). Therefore, the integrity of diplopods' morphological characteristics is weakened in standing forest and manifests itself in natural forests. Relative potency value of correlation pleiades can be used for diagnostics of forest stands naturalization within the steppe zone of Ukraine.

\section{Acknowledgements}

This study was performed in scope of the scientific project "Ecological foundations of animal zoopertinent effects on optimization native and transformed ecosystem processes in the context of current environmental management" (registration number 0117U001207) financed by Ministry of Education and Science of Ukraine.

\section{References}

Bakhmet, O. N., \& Medvedeva, M. V. (2015). Variations in soil properties upon artificial reforestation in Karelia. Contemporary Problems of Ecology, 8(7), 838-844. doi: 10.1134/S1995425515070033

Bogyó, D., Magura, T., Nagy, D. D. \& Tóthmérész, B. (2015). Distribution of millipedes (Myriapoda, Diplopoda) along a forest interior - forest edge - grassland habitat complex. In: Tuf, I. H., Tajovský, K. (Eds) Proceedings of the 16th International Congress of Myriapodology, Olomouc, Czech Republic. ZooKeys, 510, 181-195. doi.org/10.3897/zookeys.510.8657

Brygadyrenko, V. V. (2015). Community structure of litter invertebrates of forest belt ecosystems in the Ukrainian steppe zone. International Journal of Environmental Research, 9(4), 1183-1192. doi: 10.22059/IJER.2015.1008

Chibrik, T. S., Lukina, N. V., Filimonova, E. I., Glazyrina, M. A., Rakov, E. A., Maleva, M. G. \& Prasad, M. N. V. (2016). Biological recultivation of mine industry deserts: Facilitating the formation of phytocoenosis in the middle Ural region, Russia. In: Prasad, M.N.V. (ed) Bioremediation and Bioeconomy, 1st edn. Elsevier, 389-418. doi.org/10.1016/B978-0-12-802830-8.00016-2 Didur, O., Kulbachko, Y., \& Maltsev, Y. (2018a). Impact of tropho-metabolic activity of earthworms (Lumbricidae) on distribution of soil algae within Acer platanoides L. plantation in recultivated territories of Western Donbass (Ukraine). Ukrainian Journal of Ecology, 8(2), 18-23. doi: 10.15421/2018_304

Didur, O. O., Kulbachko, Yu. L. \& Pakhomov, O. Ye. (2018b). Species Structure of Oribatid Mite Population (Acari, Oribatea) in the Forest Floor Litter in the Reclaimed Territories (Ukraine). Vestnik Zoologii, 52(4), 331-340. doi: 10.2478/vzoo-2018-0035) Faly, L. I. \& Brygadyrenko, V. V. (2007) The individual's morphological variability in Philonthus decorus (Coleoptera, Staphylinidae) populations. Naukovyy visnyk Uzhhorods'koho universytetu. Seriya biolohiya, 20, 66-71. 
Frouz, J., Keplin, B., Pižl, V., Tajovský, K., Starý, J., Lukešová, A., Nováková, A., Balık, V., Háněl, L., Materna, J., Düker, C., Chalupský, J., Rusek, J., \& Heinkele, T. (2001). Soil biota and upper soil layer development in two contrasting post-mining chronosequences. Ecological Engineering, 17, 275-284. doi.org/10.1016/S0925-8574(00)00144-0

Golovatch, S. I. \& Kime, R. D. (2009). Millipede (Diplopoda) distributions: a review. Soil Organisms, 81(3), 565-597.

Golovatch, S. I. (1997). On the main patterns of millipede diversity in Eurasia (Diplopoda). Senckenbergiana biologica, 77(1), 101-106.

Grimaldi, M., Jiménez, J. J., McKey, D., Mathieu, J., Velasquez, E. \& Zangerlé, A. (2016). Ecosystem engineers in a self-organized soil: A review of concepts and future research questions. Soil Science, 181(3/4), 91-109. doi: 10.1097/SS.0000000000000155

Gudym, N. G. (2016). Sezonna dynamika chyselnosti Brachyiulus jawlowskii (Diplopoda, Julidae) na areni r. Dnipro [Seasonal population dynamics of Brachyiulus jawlowskii (Diplopoda, Julidae) in the Dnieper river arena]. Visnyk of Dnipropetrovsk University. Biology, ecology, 24(2), 489-494. (In Ukrainian). doi: 10.15421/011666 (in Ukrainian).

IUSS Working Group WRB (2015). World Reference Base for Soil Resources 2014, Update 2015. International soil classification system for naming soils and creating legends for soil maps. World Soil Resources Reports No. 106. FAO, Rome

Kime, R. D. \& Enghoff, H. (2017). Atlas of European millipedes 2: Order Julida (Class Diplopoda). European Journal of Taxonomy, 346, 1-299. doi.org/10.5852/ejt.2017.346

Klymenko, G., Kovalenko, I., Lykholat, Yu., Khromykh, N., Didur, O. \& Alekseeva, A. (2017). Intehralna otsinka stanu populiatsii ridkisnykh vydiv roslyn [The integral assessment of the rare plant populations]. Ukrainian Journal of Ecology, 7(2), 201-209. doi: 10.15421/2017_37 (in Ukrainian).

Klymenko, M. O., Biedunkova, O. O., Klymenko, O. M. \& Statnyk, I. I. (2018). Influence of river water quality on homeostasis characteristics of cypriniform and perciform fish. Biosystems Diversity, 26(1), 16-23. doi: 10.15421/011803

Kulbachko, Y. L. \& Didur, O. O. (2017). Morfolohichna minlyvist predstavnykiv pedobiontiv- zoofahiv na prykladi Carabus granulatus Linnaeus, 1758 (Coleoptera, Carabidae) v umovakh tekhnohennoho presu [Morphological variability of soildwelling zoophages using example of Carabus granulatus Linnaeus, 1758 (Coleoptera, Carabidae) at conditions of technogenic pressing]. Biolohiia ta Valeolohiia, 19, 51-57. http://doi.org/10.5281/zenodo.1108266 (in Ukrainian).

Lavelle, P., Dolédec, S., de Sartre, X. A., Decaëns, T., Gond, V., Grimaldi, M., Oszwald, J., Hubert, B., Ramirez, B., Veiga, I., de Souza, S., de Assis, W.S., Michelotti, F., Martins, M., Feijoo, A., Bommel, P., Castañeda, E., Chacon, P., Desjardins, T., Dubs, F., Gordillo, E., Guevara, E., Fonte, S., de Pilar, Hurtado, M., Lena, Ph., Lima, T., Marichal, R., Mitja, D., Miranda, I., Otero, T., Praxedes, C., Poccard, R., de Robert, P., Rodriguez, G., Sanabria, C., Tselouiko, S., Velasquez, A., Velasquez, E., \& Velasquez, J. (2016). Unsustainable landscapes of deforested Amazonia: An analysis of the relationships among landscapes and the social, economic and environmental profiles of farms at different ages following deforestation. Global Environmental Change, 40, 137-155. doi.org/10.1016/j.gloenvcha.2016.04.009

Masse, P. S. M., Fiemapong, A. R. N., VandenSpiegel, D. \& Golovatch, S. I. (2018). Diversity and distribution of millipedes (Diplopoda) in the Campo Ma'an National Park, southern Cameroon. African Journal of Ecology, 56(1), 73-80. doi.org/10.1111/aje.12418

Mcdonald, J. H. (2014). Handbook of biolological statistics, 3rd edn. Sparky House Publishing, Baltimore, Maryland

Prishutova, Z. G. (2001) Morphometric analysis and interpopulation variability of millipede Rossiulus kessleri (Diplopoda, Julidae) [Morfometricheskij analiz chastej tela I mezhpopuljacionnaja izmenchivost' u kivsjaka Rossiulus kessleri (Julidae)]. Zoological Journal [Zoologicheskij zhurnal], 80 (7), 789-796. (in Russian).

Sierwald, P. \& Bond, J.E. (2007). Current status of the Myriapod class Diplopoda (Millipedes): taxonomic diversity and phylogeny. Annual Review of Entomology, 52, 401-420. doi.org/10.1146/annurev.ento.52.111805.090210

Striganova, B. R. (1980). Pitanie pochvennyh saprofagov [Feeding of soil saprophages]. Nauka, Moscow (in Russian).

Terentyev, P. V., \& Zostova N. S. (1977). Praktikum po biometrii [Biometric Workshop]. LGU, Leningrad (in Russian).

Tobias, S. (2013). Preserving ecosystem services in urban regions: Challenges for planning and best practice examples from Switzerland. Integrated Environmental Assessment and Management, 9(2), 243-251. doi: 10.1002/ieam.1392

Citation: Pokhylenko, A., Lykholat, O., Didur, O., Kulbachko, Y., Lykholat, T. (2019). Morphological variability of Rossiulus kessleri (Diplopoda, Julida) from different biotopes within Steppe Zone of Ukraine. Ukrainian Journal of Ecology, 9(1), 176-182.

(cc) EY This work is licensed under a Creative Commons Attribution 4.0. License 